\title{
RELIGIOUS DEVELOPMENT MANAGEMENT IN FORMING THE CHARACTER OF CRIMINERS
}

\author{
Ahmad Nawawi Abdurrauf \\ Doctoral Student of Postgraduate Science Education School, \\ Islamic Nusantara University \\ Email: ahmadnawawi.ar71@gmail.com \\ lim Wasliman \\ Islamic Nusantara University Bandung \\ Email: iim.wasliman@gmail.com \\ M. Andriana Gaffar \\ Islamic Nusantara University Bandung \\ Email:m.andriana@gmail.com \\ Mustatul Anwar \\ Islamic Nusantara University Bandung \\ Email: mustatul.anwar@gmail.com
}

\begin{abstract}
Management of religious guidance in shaping the character of prisoners is a renewal, refinement or effort of action or activity carried out in an integrated, efficient and effective manner to obtain better results. If this guidance activity is carried out on prisoners, then religious guidance will give meaning to the prisoner to be faithful, knowledgeable and have a noble character in life and life. The process of forming good characters must be in accordance with the basis for the formation of good characters itself, namely the Al-Qur'an and the life and life examples of the Prophet Muhammad SAW. Al-Qur'an is the Word of Allah SWT in which it provides guidance for humans in various aspects, one of which is about guidelines for behavior so that humans can distinguish between good and bad.
\end{abstract}

Keywords: Management, religious development, character, prisoners.

\section{A. INTRODUCTION}

Humans created by Allah SWT have religious instincts, namely the religion of monotheism. If there are people who do not have a monotheistic religion, it is only influenced by other factors, one of which is the environment. In addition, humans are also the most noble creatures compared to other creatures of Allah SWT, the Word of Allah Qs. Al-Isra (17): 70.

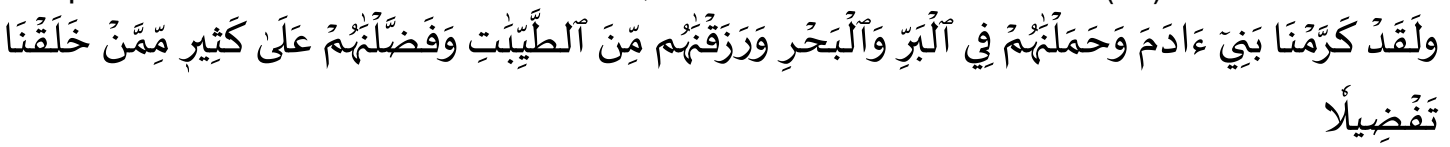

The meaning is; And Truly We have glorified the children of Adam, We carried them on land and in the sea, We gave them sustenance from the good and We magnified them with perfect 
advantages over most of the creatures that We have created (Departemen Agama Republik Indonesia, 1984).

In Islamic teachings, character (good character) is an implementation of the quality of faith and devotion that appears in intentions, words and actions that are spontaneous, easy without the need for thoughts and considerations to act. Al-Ghajali, gave a definition that Akhlaq is "a quality embedded in the soul (human), which can give birth to an action that is easy to do; without going through the intention of thinking (longer). So if this character gives rise to a commendable action according to the provisions of the ratio and religious norms, it is called good morality. But when it gives birth to bad actions, it is called bad morals (al-Ghazali, 2008).

Some of the actions that can be performed, from exemplary and / or habituation in shaping the character (good character) of prisoners, are (1). Increase introspection (muhasabah and nashuha repentance) (2). Increase Knowledge and good deeds (tafaqquh fiddin) (3). Prosperous mosques, majelis ta'lim and congregational prayer (4). Increase worship, prayer and dhikr (5). Improve life skills and religious skills

Islamic boarding school-based prisoners' religious guidance is a medium for shaping character (noble morals). Nurcholis Madjid emphasized that the pesantren is an artifact of Indonesian civilization which is constructed as a religious education institution with traditional, unique and indigenous characteristics (Haedari \& Saha, $2004: 3$ ). As an artifact of civilization, Islamic boarding schools emerge and develop from the sociological experiences of the people in their environment. In other words, pesantren have strong ties to Indonesian history and culture. It can even be said that pesantren are the deepest part of the life system of most Indonesian Muslims who are the majority group of this nation (Mastuhu, $2003: 55$ ).

\section{B. METHOD}

The method used in this research is a qualitative method with a variety of case studies. The problems that will be studied in this study use qualitative methods, which aim to find, analyze and manage direct events in the field by understanding social interactions with interviews and observations.

According to Sugiyono qualitative research methods are research methods based on philosophy, which are used to examine scientific conditions (experiments) where researchers as instruments, data collection techniques and in qualitative analysis emphasize more on meaning (Sugiyono, $2010: 213$ ).

\section{RESULT AND DISCUSSION}

\section{The concept of Islamic teachings and the concept of religious formation}

In an Islamic perspective, efforts to form the character (noble morals / good character) of prisoners must fulfill the principles of morality in Islam, namely the first principle; Believe and believe that Morals (character) are among the most important in this life, The level is after believing in Allah, in His angels, His books, His messengers, the Hereafter and His Qadha- 
qadhar. And if you believe in Allah SWT, worship Him, the mentaladani of the Prophet, then the character is first to become a human being with other human beings, then the noble character (good character) of the Prophet Muhammad SAW is an example as a basis for character building. the next character, including in shaping the character of a prisoner. According to Mikdad Yaljin that the meaning of "Innama bu'isttu liutammimma makarimal akhlaq (i) In fact I was only sent to perfect morals" The word "innama" (only) in balagah is considered a limiting cataract. So the Prophet Muhammad SAW limited the purpose of preaching "treatises" to morals. Then the word "liutammima" (to perfect) is an important word, because the apostolic task of the Prophet Muhammad was to perfect the previous samawiyah treatise, and it must be supported by noble morals (Yaljin, 1972:317).

Second principle; Believing that morals (character) are habits or attitudes deep in the soul from which deeds arise easily and easily. This is also a factor that influences human behavior and his ability to adapt himself to the natural surroundings "in which he lives. Ibn Maskawaih and Al-Ghazali said that morals are "a state or form of soul from which deeds arise without thought and effort" (Fitri, 2012). A person will not be able to change himself and his social condition unless he changes his mental and moral state. "Indeed, Allah does not change the condition of a people so that they change the condition that is in themselves. (Surah Al-Ra'd (13): 11).

Third principle; Believe that the morals based on Islamic law shown by Islamic religious texts and teachings, as well as ijtihad-ijtihad and the deeds of pious scholars and their good followers, are noble human morals. It is in accordance with a healthy nature and reason and fulfills the needs of a good individual and a noble society in all times and places and regulates all human relations with other people. It is not surprising that Islamic morality has all of these noble qualities, because its form depends on Allah SWT, its teachings, commands and prohibitions. In order to better understand the idiosyncrasies of these morals, we can look at its characteristics, namely (a) Overall (universal) (b) Balance (c) Simple (d) Realism: (e) Convenience (f) Balance of words and actions.

The fourth principle; Believing that the highest goal of religion and morals is to create happiness in the world and the hereafter, the perfection of the soul for the individual and to create.

Fifth Principle; Believe and believe that Islam is the main source for noble morals and the most important factor that influences lifestyle and gives an Islamic style that differentiates it from others. Muhammad Abdullah Darraz (1972: 23) emphasizes that the essence of religion is good character, namely the creation of God's servants who guide "truth and goodness". (Surah Al-Isra (17): 9).

Sixth principle; Believing that a theory of morality is not perfect unless it contains five main aspects, namely: (1) Moral Conscience (2) Moral Obligation (3) Moral Judgment (4) Responsibility Moral Responsibility (5) Moral Rewards (Syahidin, 2009).

The aim of the treatment of prisoners in Indonesia is that the purpose of punishment is correctionalism, so those who become prisoners are no longer deterred but are nurtured to be 
re-socialized. The purpose of coaching is correctional, can be divided into three things, namely:

1. After leaving the Correctional Institution no longer committing a criminal act.

2. Become a useful human being, play an active and creative role in building the nation and country.

3. Able to get closer to God Almighty and get happiness in this world and the hereafter.

Meanwhile, based on the first Correctional Directorate Service Conference in Lembang (Bandung) on April 27, 1964, further formulation of the aims and objectives of imprisonment is known as the 10 main principles of correctionalism, namely:

1. Ayomi and give a provision for the life of the Correctional Assistance Community (WBP) so that later they can carry out their role as good and useful citizens of the community.

2. Criminal is not revenge from the state. This means that there should be no torture to prisoners, whether in the form of words, actions, treatment and placement.

3. Provide guidance, not by means of torture with the aim of repenting, knowing the norms of life and social activities that foster a sense of community life.

4. The state has no right to make WBP even worse than before he was convicted.

5. As long as their independence is limited, WBP may not be isolated from the community. There needs to be contact with the community in the form of visits or entertainment to prisons by community members, opportunities to gather and meet family and friends. The reason is, this is a necessity in the correctional process.

6. The lessons given to the WBP must not be a time filler to meet the answer needs or the interests of the state, except at certain times. The lessons given are lessons that are integrative with the potential that exists in society.

7. Coaching or guidance given to WBP must be based on Pancasila.

8. WBP must be given guidance or guidance to the right path.

9. WBP was sentenced to a punishment in the form of restrictions on his independence within a certain period of time.

10. For guidance and guidance, WBP is provided or provided with the necessary facilities.

Manajemen Pembinaan : Pelaksanaan pembinaan keagamaan Narapidana

The implementation of coaching is the most important element of the management function, it will only have meaning, if the plan can be carried out in the form of real activities, without the implementation of a certain coaching plan which, although it has been neatly arranged, is only on paper. From here, the implementation function plays a very important role. There are 5 (five) cultivated fields which are the main elements for the implementation of the religious guidance of the Prisoners in shaping the character of the Prisoners, namely:

Who does religious formation; From various verses of the Al-Qur'an and the Hadith of the Prophet Muhammad, it can be concluded that every individual Muslim who is mature is a preacher, meaning that he must carry out the task of religious formation or in simple language, the task of da'wah is in accordance with their respective fields and abilities in the context of amar ma'ruf nahi evil (Khusni, 2018).

To whom is religious formation; Guidance for inmates is known as a correctional facility and is carried out by correctional officers. Development of Prisoners as regulated in the Correctional Law, development of prisoners is also regulated in Government Regulation No.31 of 1999 concerning Guidance for Correctional Assistance (hereinafter written PP No.31 of International Journal of Nusantara Islam Vol. 07 No. 02 2019: (338-344) DOI: 10.15575/ijni.v7i2.12585 
1999), namely in the provisions of: Article 2 PP No. 31 of 1999; 1) coaching and mentoring programs include personality and independence coaching and guidance activities, 2) coaching programs intended for prison inmates and correctional students, 3) mentoring programs (Koesoema, 2010).

How are the methods and techniques of religious formation (a) Anticipatory Function; All issues relating to values and life systems constitute a challenge in the religious fostering of prisoners as a potential generation of the people and nation. In this regard, there are several characteristics of anticipatory religious development, namely: (1). Multidialog religious formation; which is personal, there is (a). information / knowledge dialogue (b). Value dialog (c). Dialogue of ideas, ideas, or concepts (d). Aesthetic dialogue / cultural arts (e). Charity or work dialogue (f). Spiritual or community dialogue such as; (a). Economic dialogue (b). Sociocultural-political dialogue (2). Information dialogue. (b) The practice of religious formation; The practice of religious guidance carried out by the Prophet Muhammad, consists of 4 (four) aspects, namely; Noble moral aspects and character, method and technique aspects, communication \& language aspects (Syahidin, 2009a).

In the aspect of communication and effective language, it is an effective way to preserve the nature and values of heroism, act and work through polite, assertive and professional language, including (1) Qaulan Ma'rufan / good literature, language according to tradition, (2) ) Qaulan Kariman / noble words, have the meaning of respect, easy to hear and there is an element of politeness. (3) Qaulan Maysuran / appropriate speech, easy to understand and soothing to feelings (heart). (4) Qaulan Balighan / words that hit / deep, are right on target / objective, effective and cost efficient, time and place. (5) Qaulan Layyinan / gentle speech, smooth, penetrates the heart's recess, does not offend and is pleasant to hear. (6) Qaulan Sadidan / words that are true / balanced, fair from both sides. (7) Qaulan Adzima / words that have weight, are profound in their material and have weight in their content. (8) Qaulan Mirrabbirrahim / Rabbani's words, comes from God / contains divine messages (9) Qaulan Tsaqila / words are heavy, weighty, contain messages-information, human obligations, shari'ah, halal-haram and criminal-civil law.

For the Aspect of Leadership; Namely leadership with divine values that rely on the AlQur'an and as-sunnah. Since childhood, Rasulullah saw was forged with various kinds of tests and trials that were insistent, but he was still patient, sincere and tawakkal, his life was based on morality; such as the title Al-Amin (trusted), the existence of STAF, namely Shiddiq (Honest), Tabligh (convey), Amanah (responsibility / professional) and Fathanah (Intelligent) (Wahjosumidjo, 2002).

What is the material or material for religious formation; Broadly speaking, there are two coaching contents or materials, namely (1). Ubudiyah aspects and (2). Aspects of Mua'ammalah. According to Toha Yahya Omar, MA in Da'wah Science, that the material of religious guidance is; (a) Straighten i'tikad to the true Aqidah (b) Expanding and deepening the knowledge of the Islamic Diinul in Kaffah-totality. (c) Continuing and expanding righteous deeds (d) Cleansing the soul (heart) (e) Strengthening personality (noble morals) (f) Strengthening ukhuwah Islamiyah, through ta'ruf, tafahum, ta'awun and takaaful (g) Rejecting religious syubhat (Syarifah, 2018).

How are the Media and Development tools; What is meant by media and development tools are (a) media / development tools, material or person (man) or human that has a meaningful influence on students such as mosques / mushalla, educators, families and schools. In the language of Islamic education it is called wasa'ith al-tarbiyah (education \& International Journal of Nusantara Islam Vol. 07 No. 02 2019: (338-344) DOI: 10.15575/ijni.v7i2.12585 
teaching factor). (b) Media / guidance tools, which are psychic or meaningful towards students such as storytelling, dialogue or role models, in the language of Islamic education it is called as'alib or wasa'il al-tarbiyah (education \& teaching method.).

\section{CONCLUSSION}

Good character is fundamental and essential, requiring a series of processes and stages, namely the management of religious guidance in shaping the character of prisoners as divine and human endeavors.

To form the character of a prisoner, he must pay attention to mental processing (theory of mental processing). The important thing is how to make the mind and heart in us always defeat our lust in every battle between conscience and dzulmani, so that the positive potential can be explored. maximally to produce lights that are manifested in our high moral values. Character education (noble morals) needs to begin with the stages of soul purification so that a person can feel close to God "qarib", where the first effort made is cleansing the soul from despicable qualities which then after the soul is clean filled with commendable qualities. so that the emission of Nur llahiyah is obtained. Prioritizing aspects of nothingness (exemplary theory); Exemplary is needed because it is not uncommon for abstract values to be incomprehensible. Abstract things are explained by concrete parables. Exemplary is needed because it has a very large ability in transferring values, traits and character. In everyday life, it can be seen that the examples given by people who are considered good and respectable can spread quickly and easily in the midst of society. Shaping character through habituation theory. Habituation must begin with a serious effort to impose oneself, even if necessary, make up activities that are considered good with the aim of shaping character, not because of hypocrisy. Shaping character through the environment (environmental theory); The environment has a very big influence in shaping a person's character (noble morals), both the natural environment itself and the social environment. The character (noble morals) of a person is very determined and influenced by the environment in which the person lives. Management of Religious Guidance in shaping the character of inmates based on Islamic boarding schools is an appropriate endeavor, as a contribution to creating convict khairunnaas anfa'uhum linnas.

\section{References}

al-Ghazali, I. (2008). Ringkasan Ihya' Ulumuddin. Akbar Media.

Departemen Agama Republik Indonesia. (1984). Al-Quran dan Terjemahnya. Yayasan Penyelenggara Penterjemah Al-Qur'an.

Fitri, A. Z. (2012). Pendidikan Karakter. Arruz Media.

Haedari, M. A., \& Saha, M. I. el-. (2004). Panorama pesantren dalam cakrawala modern. Diva Pustaka. 
Khusni, Moh. F. (2018). Fase Perkembangan Anak Dan Pola Pembinaannya Dalam Perspektif Islam. Martabat: Jurnal Perempuan Dan Anak - Pusat Studi Gender Dan Anak (PSGA) IAIN Tulungagung, 2(2), 361-382. https://doi.org/10.21274/martabat.2018.2.2.361-382

Koesoema, A. D. (2010). Pendidikan Karakter Strategi Mendidik Anak di Zaman Global. PT. Grasindo.

Mastuhu. (2003). Menata ulang pemikiran sistem pendidikan nasional dalam abad 21. MSI, Universitas Islam Indonesia.

Sugiyono. (2010). Metode Penelitian Pendidikan Pendekatan Kuantitatif, kualitatif, dan R\&D. Alfabeta.

Syahidin. (2009). Moral dan Kognisi Islam. CV Alfabeta.

Syarifah, M. (2018, February 1). Materi Pendukung Literasi Digital. Mushlihatun Syarifah. https://www.msyarifah.my.id/materi-pendukung-literasi-digital/

Wahjosumidjo. (2002). Kepemimpinan dan Motivasi. Ghalia Indonesia.

Yaljin, M. (1972). Al-Ittijah Al-Akhlaqi fi Al-Islam. Dirasah Muqaranah. 